\title{
Almitrine: a possible therapeutic strategy for COVID-19?
}

\author{
Almitrina: uma posssível estratégia terapêutica \\ para COVID-19?
}

\section{Almitrina: ¿una posible estrategia terapéutica para COVID-19?}

\section{Renata Maria de Carvalho Cremaschi ${ }^{1}$, Cristina Frange ${ }^{2}$, Lia Rita de Azeredo Bittencourt ${ }^{3}$, Fernando Morgadinho Santos Coelho ${ }^{3}$}

1.MD, PhD, Neurology and Neurosurgery Department, Universidade Federal de São Paulo, São Paulo-SP, Brazil.

2.PT, PhD, Neurology and Neurosurgery Department, Universidade Federal de São Paulo, São Paulo-SP, Brazil.

3.MD, PhD, Neurology and Neurosurgery Department, Psychobiology Department, Universidade Federal de São Paulo, São Paulo-SP, Brazil.

\section{Resumo}

O COVID-19 continua sem tratamento específico, apesar dos esforça de muitos cientistas ao redor do mundo. O Severe Acute Respiratory Syndrome Coronavirus 2 (SARS-COV-2) penetra nas cédulas hospedeiras humanas através da interação com os receptores da enzima conversora de angiotensina 2 e da serino protease transmembranar 2 (TMPRSS2), do trato respiratório (superior e inferior) e do epitélio olfatório (via de entrada para o Sistema Nervoso Central). O vírus causa a COVID-19 e às vezes uma Síndrome Respiratória Aguda Grave (SRAG). Diversas manifestações neurológicas podem estar associadas à infecção. $O$ neurotropismo do SARS-COV-2 para centros autonômicos cardiorrespiratórios, causando lesão autonômica, pode contribuir parcialmente para a insuficiência respiratória. A almitrina é uma potente droga estimulante respiratória, usada em doenças hipoxêmicas crônicas. Atua nos quimiorreceptores periféricos e pode ser um tratamento em potencial para a otimização dos quimiorreceptores, melhorando o controle respiratório afetado pela SARS-CoV-2.

Unitermos. Infecções por coronavirus; disautonomia; neurologia

\begin{abstract}
Coronavirus disease 2019 (COVID-19) remains with no specific treatment, despite the efforts of many scientists around the world. Severe Acute Respiratory Syndrome Coronavirus 2 (SARS-COV-2) penetrates human host banknotes through interaction with angiotensinconverting enzyme 2 and transmembrane protease, serine 2 (TMPRSS2) receptors, located at respiratory tract (upper and lower) and the olfactory epithelium (pathway to the Central Nervous System). The virus causes COVID-19 and sometimes a Severe Acute Respiratory Syndrome (SARS). Several neurological manifestations can be associated with the infection. The SARS-COV-2 neurotropism for cardiorespiratory centers, causing autonomic damage, may contribute to respiratory failure. Almitrine is a respiratory stimulant drug, used in chronic hypoxemic diseases. Almitrine acts in peripheral chemoreceptors and could be a potential treatment for the optimization of chemoreceptors, improving the respiratory control affected by the SARS-CoV-2 in patients with COVID-19.
\end{abstract}

Keywords. Coronavirus Infections; dysautonomia; neurology 
COVID-19 permanece sin tratamiento, a pesar de los esfuerzos de muchos científicos de todo el mundo. Síndrome respiratorio agudo severo coronavirus 2 (SARS-COV-2) penetra en los billetes del huésped humano mediante la interacción con los receptores de la enzima convertidora de angiotensina 2 y la serina proteasa 2 transmembrana (TMPRSS2), el tracto respiratorio (superior e inferior) y epitelio olfatorio (vía hacia el sistema nervioso central). El virus causa COVID-19 y, a veces, un síndrome respiratorio agudo severo (SARS). Varias manifestaciones neurológicas pueden estar asociadas con la infección. El neurotropismo del SARS-COV-2 en los centros cardiorrespiratorios autónomos, que causa lesión autónoma, puede contribuir parcialmente a la insuficiencia respiratoria. La almitrina es un potente estimulante respiratorio que se utiliza en enfermedades hipoxémicas crónicas. Actúa sobre quimiorreceptores periféricos y puede ser un tratamiento potencial para la optimización de quimiorreceptores, mejorando el control respiratorio afectado por el SARS-CoV-2.

Palabras clave. Infecciones por coronavirus; disautonomía; neurología

This work was performed at the Universidade Federal de São Paulo, São Paulo-SP, Brazil.

Conflict of interest: no Received in: 21/07/2020 Acept in: 23/10/2020

Correspondent Address: Fernando MS Coelho. R. Pedro de Toledo 650, Vila Clementino, CEP 04039-002, São Paulo-SP, Brazil. Phone + 55 1155764848 ext. 2904. Email: fernandomorgadinho@hotmail.com

\section{To the Editor,}

Recently, a new pathogenic coronavirus called severe acute respiratory syndrome coronavirus 2 (SARS-CoV-2) drives a potential lethal coronavirus disease (COVID-19), that remains with no treatment, despite the efforts of many scientists around the world. Most symptoms in humans are characterized by mild respiratory problems, however, in older patients there is a greater risk of developing SARS. Even though respiratory symptoms are most common, other symptoms such as headache and enteric diseases (e.g. nausea and vomiting) are seen frequently ${ }^{1}$. Hyposmia and anosmia are recently recognize in great part of patients too ${ }^{2}$. Neurological manifestations (central, peripheral, and neuromuscular) was described in more $50 \%$ of hospitalized patients ${ }^{3}$. 
Patients with COVID-19 develop fever, cough, shortness of breath, and dyspnea, and many might develop pneumonia, respiratory distress, kidney failure, and death ${ }^{4}$. Dyspnea is seen in more than half of the most severe patients. Clinical worsening during infection can be rapid with progressive respiratory failure requiring oxygen therapy and/or artificial ventilation. Indeed, almost $90 \%$ of patients who require intensive care are not able to spontaneously breathe ${ }^{5}$. In addition, older patients and those with other medical conditions have a higher risk of rapid progressive ventilatory insufficiency. The neurotropism of SARS-CoV-2 for the Central Nervous System (CNS) can have a potential contribution to respiratory failure in patients with COVID$19^{6}$.

The entrance of SARS-CoV-2 into human host cells is mediated by the angiotensin-converting enzyme 2 (ACE2) and transmembrane protease, serine 2 (TMPRSS2) receptors, which is expressed in the airway's epithelium, lung parenchyma, vascular endothelium, renal, intestine, and CNS cells (cortex, striatum, and brainstem). The CNS invasion depends on interaction between SARS-CoV-2 and ACE2. The Central Autonomic Network (CAN) is part of CNS that include regions with high ACE2 expression, such as Hypothalamus, Nucleus of Solitary Tract (NST), and Rostral reticular formation of the Ventrolateral Medulla (RVLM). In theory, the SARS-CoV-2 attacks the CAN, contributing to the collapse of ventilatory command centers and consequent acute respiratory insufficiency ${ }^{1}$. 
Animal research, with viruses similar to the SARS-CoV2 , demonstrates the invasion of the virus in the CNS through the olfactory nerves with rapidly dissemination to CAN areas (Thalamus and Brainstem)7 . Brainstem Respiratory Network (BRN), NST, and RVLM drives rhythm of breathing and regulates central chemosensitivity controlling hypoxia and hypercapnia. RVLM project to sympathetic neurons in the spine to regulate blood pressure too. Neurons of RVLM, originated from the NST which respond to baroreflex efferent are sympathoinhibitor inputs to RVLM. RVLM-spinal pathway intermediates baroreflex, cardiopulmonary reflexes and chemoreflexes. Breathing results from the interaction of pontine respiratory regions linked to RVLM, influenced by feedback of respiratory chemoreceptors in brainstem, mainly in the medulla region named retrotrapezoid nucleus (RTN). Indeed, RVLM increases respiratory rate and tidal volume, responding to hypoxia and hypercapnia ${ }^{8}$.

SARS-CoV-2, has a larger interaction with ACE2 receptors, and it is possible a viral sprouting cycle accompanied by neuronal dysfunction without substantial inflammation ${ }^{9}$. SARS-CoV-2 may attack CAN after CNS invasion, and nasal contamination could lead to a more aggressive disease, compared to fecal-oral or conjunctival routes. In smokers, nicotine regulates acetylcholine receptors in neurons and astrocytes, which promote greater viral replication through increased expression of ACE2 and dysfunction of RVLM ${ }^{6}$. An autonomic dysfunction, caused by 
CAN impairment, mainly in RVLM, impacts on an unfavorable ventilatory outcome.

No specific therapeutic drug or vaccine has been approved for the treatment of COVID-19. Advanced life support with mechanical ventilation and intensive care has been the best option to help the most severely ill patients. A few drugs are in the process of clinical study, such as chloroquine, azithromycin, zinc, among others. In this unfavorable scenario, the search for a drug or treatment to improve patients with COVID-19 is an emergency and imperative ${ }^{10}$.

Almitrine is a respiratory stimulant which was used in chronic hypoxemic diseases, and acts in peripheral chemoreceptors. It is a potent stimulant of carotid bodies, optimizing ventilatory and gasometrical parameters through peripheral chemoreceptor stimulation ${ }^{11}$. There are evidence on the interaction between central chemoreceptor stimulation and RVLM sympathomimetic neurons that exhibit patterns of central respiratory activity similar to those of sensitive sympathetic ganglion neurons ${ }^{12}$. The optimization of chemoreceptors could help the respiratory control affected by the SARS-CoV- 2 .

To improve the possible CAN dysfunction by COVID-19, we recommend clinical investigations with Almitrine to treat patients with COVID-19 and studies about its impact on the possible dysautonomia. Unfortunately, in Brazil we do not have access to this drug to conduct a clinical trial. Theoretically, the optimization of the central chemoreceptors 
by Almitrine could improve the CAN affected by the SARS-

CoV-2 helping patients with COVID-19 and shortening days of hospitalization after improvement of ventilatory parameters. We suggest that Almitrine could be useful to treat patients with COVID-19.

\section{REFERENCES}

1.Li YC, Bai WZ, Hashikawa T. The neuroinvasive potential of SARSCoV2 may play a role in the respiratory failure of COVID-19 patients. J Med Virol 2020;Epub ahead of print. https://doi.org/10.1002/jmv.25728

2.Lechien JR, Chiesa-Estomba CM, De Siati DR, Horoi M, Le Bon SD, Rodriguez A, et al. Olfactory and gustatory dysfunctions as a clinical presentation of mild-to-moderate forms of the coronavirus disease (COVID-19): a multicenter European study. Eur Arch Otorhinolaryngol 2020;277:2251-61.

https://doi.org/10.1007/s00405-020-05965-1

3. Mao $L$, Jin $\mathrm{H}$, Wang $\mathrm{M}$, $\mathrm{Hu} \mathrm{Y}$, Chen $\mathrm{S}$, He $\mathrm{Q}$, et al. Neurologic Manifestations of Hospitalized Patients With Coronavirus Disease 2019 in Wuhan, China. JAMA Neurol 2020;1-13. Epub ahead of print. https://doi.org/10.1007/s00415-020-09974-2

4.Lescure FX, Bouadma L, Nguyen D, Parisey M, Wicky PH, Behillil S, et al. Clinical and virological data of the first cases of COVID-19 in Europe: a case series. Lancet Infect Dis 2020;20:697706. https://doi.org/10.1016/S1473-3099(20)30200-0

5.Li JY, You Z, Wang Q, Zhou ZJ, Qiu Y, Luo R, et al. The epidemic of 2019-novel-coronavirus (2019-nCoV) pneumonia and insights for emerging infectious diseases in the future. Microbes Infect 2020;22:80-5. https://doi.org/10.1016/j.micinf.2020.02.002

6.Kabbani N, Olds JL. Does COVID19 Infect the Brain? If So, Smokers Might $\mathrm{Be}$ at a Higher Risk. Mol Pharmacol 2020;97:351-3. https://doi.org/10.1124/molpharm.120.000014

7.Dube M, Le Coupanec A, Wong AHM, Rini JM, Desforges M, Talbot PJ. Axonal Transport Enables Neuron-to-Neuron Propagation of Human Coronavirus OC43. J Virol 2018;92:e00404-18.

https://doi.org/10.1128/JVI.00404-18

8.Li YC, Bai WZ, Hirano N, Hayashida T, Hashikawa T. Coronavirus infection of rat dorsal root ganglia: ultrastructural characterization of viral replication, transfer, and the early response of satellite cells. Virus Res 2012;163:628-35.

https://doi.org/10.1016/j.virusres.2011.12.021 
9.Li YC, Bai WZ, Hirano N, Hayashida T, Taniguchi T, Sugita $Y$, et al. Neurotropic virus tracing suggests a membranous-coating-mediated mechanism for transsynaptic communication. J Comp Neurol 2013;521:203-12. https://doi.org/10.1002/cne.23171

10.Md Insiat Islam Rabby. Current Drugs with Potential for Treatment of COVID-19: A Literature Review. J Pharm Pharm Sci 2020;23:58-64. https://doi.org/10.18433/jpps31002

11.Smith PD, Gotz VP, Ryerson GG. Almitrine bismesylate. Drug Intell Clin Pharm 1987;21:417-21. https://doi.org/10.1177/106002808702100503

12. Moreira TS, Takakura AC, Colombari E, Guyenet PG. Central chemoreceptors and sympathetic vasomotor outflow. J Physiol 2006;577:369-86. https://doi.org/10.1113/jphysiol.2006.115600 